International Research Journal of Management, IT \& Social Sciences
Available online at https://sloap.org/journals/index.php/irjmis/
Vol. 6 No. 4, July 2019, pages: 135 146
ISSN: 2395-7492
https://doi.org/10.21744/irjmis.v6n4.667

\title{
Technology Acceptance Application Model on Internet Banking Service in BRI Bank Denpasar Indonesia
}

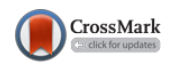

Ari Melaning a

I Gst Ayu Kt. Giantari ${ }^{\text {b }}$

\section{Article history:}

Received: 09 March 2019

Accepted: 31 May 2019

Published: 06 July 2019

\section{Keywords:}

attitude;

behavioral;

intention of use;

perceived ease of use;

perceived usefulness;

\begin{abstract}
This study aims to explain the effect of perceived usefulness, and perceived ease of use, on attitude toward using, and behavioral intention of use at BRI banks Denpasar. The technique used to test the research hypothesis uses Structural Equation Modeling (SEM) analysis techniques using SMARTPLS assistance, using IBM SPSS Statistics 22. The population in this study were all BRI Bank customers in Denpasar who used Internet Banking, the number of samples in this study was 150 respondents, who were taken using Purposive Sampling techniques. The results showed that (1) the attitude toward using had a positive and significant effect on the behavioral intention of use (2) perceived ease of use had a positive and significant effect on attitude toward using (3) perceived usefulness had a positive and significant effect on the behavioral intention of use. (4) perceived ease of use has a positive and significant effect on the behavioral intention of use (5) perceived usefulness has a positive and significant effect on attitude toward using. (6) attitude toward using can mediate the relationship between perceived usefulness to the behavioral intention of use. (7) the attitude toward using can mediate the relationship between perceived ease of use on the behavioral intention of use.
\end{abstract}

2395-7492@ Copyright 2019. The Author. This is an open-access article under the CC BY-SA license (https://creativecommons.org/licenses/by-sa/4.0/) All rights reserved.

\section{Author correspondence:}

Ari Melaning,

Faculty of Economics and Business, Udayana University, Denpasar, Indonesia

Email address: rasumaputri80@gmail.com

\section{Introduction}

Currently, BRI is innovating services by focusing on information system technology by launching the "BRISAT" Satellite in 2016 to improve service quality so that it can reach the entire archipelago. Until 2015 BRI had 10,200 office units (economy, replubika.co.id December 31, 2014) that were spread throughout Indonesia with online and connected transaction activities. So that information technology is expected to become the leading bank in Indonesia (Chanana \& Gupta, 2016).

\footnotetext{
a Faculty of Economics and Business, Udayana University, Denpasar, Indonesia ${ }^{\mathrm{b}}$ Faculty of Economics and Business, Udayana University, Denpasar, Indonesia
} 
Like electronic transaction services (e-banking) through ATMs, phone banking and Internet Banking, for example, are new forms of bank services and change manual transaction services into technology-based transaction services. Bank Indonesia often uses the term Information System Technology (TSI) Banking for all applied information and communication technologies in banking services. With the increasing prestige of internet and mobile phone use, the development of electronic banking (e-channel) networks has become very important for the company's business to maintain customer loyalty (Yoga, 2012).

Internet banking answers the demands of customers who want a fast, safe, convenient, inexpensive service, available 24 hours and can be accessed from anywhere, both cell phones, computers, and laptops (Suryasa et al., 2018; Udayana, 2017). Internet banking is one of the banking services that enable customers to obtain information, communicate and conduct banking transactions through the internet network, and is not a bank that only provides banking services through the internet (Tampubolon, 2004).

Internet banking helps banks to cut transaction costs, improve the image on the market, and provide a better response to market demand (Kerem, 2003). In a study conducted by Kaleem \& Ahmad (2008), in Pakistan mentioned e-banking as a means to minimize inconvenience, reduce transaction costs and save time. The ease of obtaining information and the many benefits gained increases the use of information systems (Lech, 2012). The advantage of providing internet banking services can be a cheap solution to infrastructure development rather than opening an ATM outlet. Banks do not have to have branch offices, save operational costs and fixed costs by replacing employee functions and physical facilities with information technology (Manzano et al., 2009).

The Technology Acceptance Model (TAM) offers a strong and simple explanation for the acceptance of technology and the behavior of its users (Rocker, 2009). Expansion of the TAM concept is expected to help predict one's attitudes and acceptance of technology and can provide the basic information needed regarding the factors that drive the individual's attitude (Lee, 2010). TAM theorizes that one's intention to use a system or technology is determined by two factors, perceived usefulness, is the level of individual trust that the use of technology will improve its performance, and perceived ease of use, is the level of individual trust that the use of technology makes it easier to complete work (Davis, 2000). Attitude Toward Using, namely the attitude towards the application of something according to (Rocker, 2009) is a pro or contra attitude towards the application of a product. The attitude of the pros or cons of a product can be applied to predict the behavior or intention of someone to use a product or not to use it. The attitude towards the use of technology applications (attitude toward using technology), is interpreted as an evaluation of the user about his curiosity in using technology (Dewi et al., 2017).

Behavioral intention to use is the tendency of behavior to keep applying a technology (Rocker, 2009). The level of use of computer technology on a person can be predicted from the user's attitude and attention to the technology, for example, is the desire to add supporting peripherals, the desire to keep using, and the desire to influence other users. Bank Rakyat Indonesia (BRI), has one Electronic Banking Platform for banks with various delivery channels in the past few years. All financial transactions increase from year to year at BRI, not so with internet banking. This indicates a crisis of customer confidence in internet banking offered by BRI. And this is one of the weaknesses of BRI banks that will be utilized by other banks (Alamsyah, Anugrah, 2015).

This research is a replication of previous research conducted by (Rocker, 2009). Perceived ease of use and perceived usefulness both have an influence on the behavioral intention of use and influence the attitude toward using. Technology users will determine the attitude of using technology if they feel the technology system is useful and easy to use, and use it continuously. Perceived ease of use and perceived usefulness and also affect the behavioral intention of using directly without being preceded by the attitude toward using. In Indonesia, there are several studies that use the TAM concept in internet banking adoption, namely research conducted by Medyawati et al., (2011), in Bekasi, Kusuma \& Susilowati (2007), in Yogyakarta, and Widyarini (2005), in Surabaya. Therefore, it is necessary to prove whether ease of use and usefulness can influence the attitude toward using and behavioral intention of use and internet banking at PT. Bank Rakyat Indonesia in Denpasar.

\section{Literature Review}

\section{Internet banking}

Internet banking is a bank service that allows customers to obtain information, communicate and conduct banking transactions through the internet network, and is not a bank that only provides banking services through the internet (Bank Indonesia, 2004). Basically internet banking technology that has been made by the banking world has benefits for banks, namely the efficiency of banking performance in the use of paper because everything is already through the 
internet and can be a source of income derived from service fees charged to customers. Banks that use internet banking provide low-cost services for customers (Kustina et al., 2018).

\section{Technology Acceptance Model (TAM)}

In TRA, behavior is a set of actions and actions of a person in responding to something and then used as a habit because of the values believed. The user of a system is determined by individual perceptions and attitudes which will ultimately shape a person's behavior in the use of an information technology. TAM is used to see individual understanding that continuously uses information technology in its activities, this was stated by Sanjaya (2005). The use of information systems in individuals to carry out activities and their use is still an important concern for researchers, although there are significant advances in the capabilities of hardware and software. The high the of an information system signifies the usefulness and ease of an information system. Someone will use the information system on the grounds that the system will produce benefits for themselves.

\section{Perceived Usefulness}

Perceived usefulness is defined as a measure where the use of a technology is believed to bring benefits to those who use it (Wen \& Chia Tsai, 2012). Also stated on (Rocker, 2009) perceived usefulness as a subjective ability of users in the future where using a specific application system will improve performance in the context of the organization. The same thing was expressed by Shun conceptualizing that perceived usefulness is measured through indicators such as improving job performance, making work easier and overall technology used is felt useful. In the research of Yahyapour (2008), it was added that perceived usefulness can be measured by indicators increasing productivity, making work more effective, and work becoming faster and more efficient.

\section{Perceived Ease of Use}

Rocker (2009), states that perceived ease of use is a technology defined as a measure where one believes that a computer can be easily understood and used. This definition is also supported by Wibowo (2006), who states that perceptions about the ease of use of a technology are defined as a measure where one believes that the technology can be easily understood and used. In Rocker (2009), also defines the perception of ease of use as a measure where future users assume a system is barrier free. The indicators used to measure perceived ease of use are easy to learn, flexible, can control work, and are easy to use according to Yahyapour (2008).

\section{Attitude toward Using}

Attitude toward using in TAM is conceptualized as an attitude towards the use of a system in the form of acceptance or rejection as a result if someone uses a technology in their work (Rocker, 2009). In Hoppe et al., (2001), the attitude toward using is the attitude of explaining one's acceptance of information technology. In Widyarini (2005), stated attitude is a behavior that states what we like and do not. The attitude in Yahyapour (2008), is defined as one form of evaluation of the consequences of carrying out a behavior. According to Yahyapour (2008), attitudes toward using internet banking can be measured by indicators, internet banking technology is fun to use, the use of internet banking is the right idea because it can provide comfort in its use.

\section{Behavioral Intention of Use}

Behavioral intention to use is a behavioral tendency to keep applying a technology (Wen-Chia Tsai, 2012). The level of use of an Internet Banking technology on a person can be predicted from the user's attitudes and attention to the technology, for example the desire to add supporting peripherals, the desire to keep using, and the desire to influence other users. According to Kusuma \& Susilowati (2007), Behavioral Intention of Use internet banking is measured by indicators of internet banking usage used continuously, can meet needs. According to Rigopoulos \& Askounis (2007), Behavioral intention to use is measured by indicators of internet banking usage is always needed in each transaction so that it can motivate other customers to transact using internet banking.

Melaning, A., \& Giantari, I. G. A. K. (2019). Technology acceptance application model on internet banking service in BRI Bank Denpasar Indonesia. International Research Journal of Management, IT and Social Sciences, 6(4), 135146. https://doi.org/10.21744/irjmis.v6n4.667 


\section{Research Hypothesis}

H1: Perceived usefulness has a positive and significant effect on Attitude toward using Internet Banking.

H2: Perceived ease of use has a positive and significant effect on Attitude toward using Internet Banking.

H3: Perceived usefulness has a positive and significant effect on Internet Banking Behavioral intention of use.

H4: Perceived ease of use has a positive and significant effect on the Behavioral intention of use of Internet Banking.

H5: Attitude toward using has a positive and significant effect on Internet Banking Behavioral intention of use.

H6: Attitude toward using is supposed as a mediation of Perceived usefulness for Internet Behavioral intention of use Internet Banking.

H7: Attitude toward using is supposed as a mediation of Perceived ease of use on behavioral intention of use Internet Banking.

\section{Conceptual Framework}

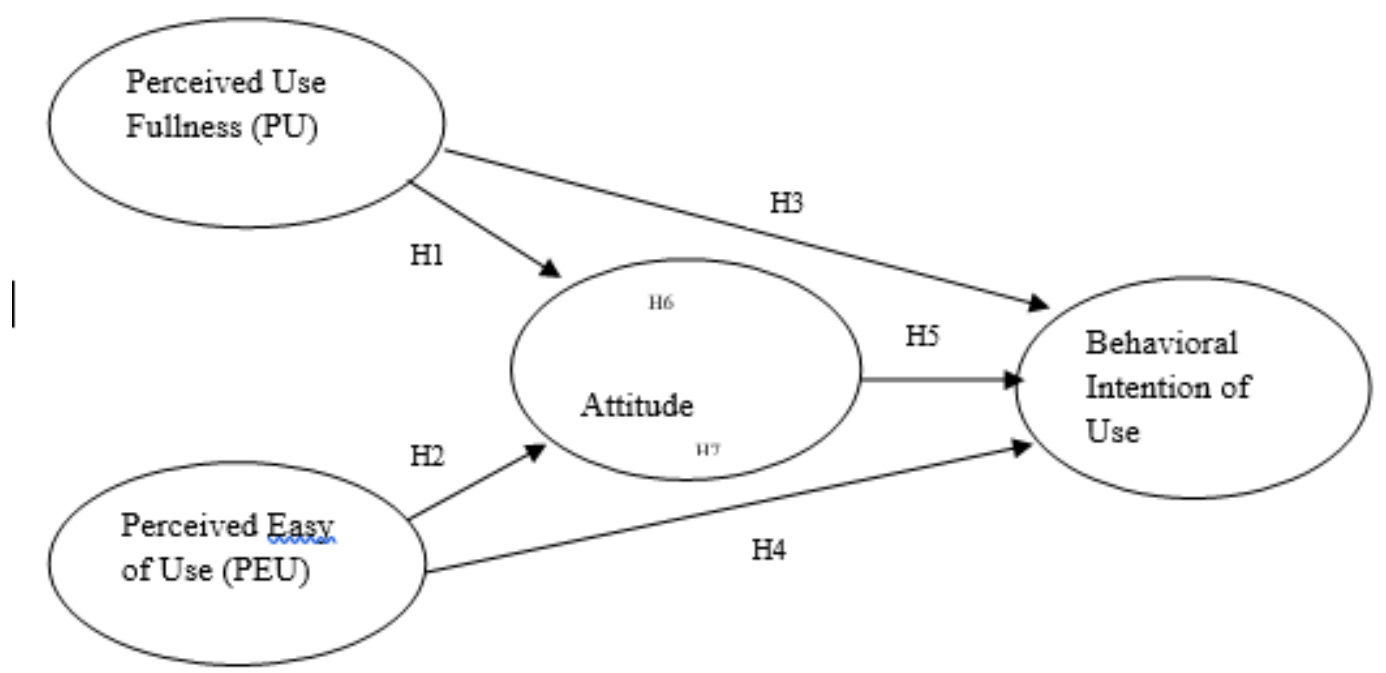

\section{Materials and Methods}

\section{Research design}

Data analysis was performed using descriptive statistical analysis techniques and inferential statistical analysis, namely Partial Leas Square (PLS). To find out the relationship of independent variables to the dependent variable through the moderating variable, then after testing the hypothesis, then proceed with the mediation test (sobel test). The results of the analysis are then interpreted, then the final step is given conclusions and suggestions. The discussion in this study includes the relationship between full use perceived variables, perceived easy of use, attitude toward using and behavioral intention of use.

The scope of this research is limited to BRI Bank customers who use Internet Banking facilities in Denpasar City. The data collection technique of this research is survey research which is obtained through distributing questionnaires to a group of people as members of the sample who are considered to represent the population. The questionnaire contains a number of statements related to perceived use fullness, perceived easy of use, attitude toward using and behavioral intention of use BRI Internet Banking customers in Denpasar. 


\section{Results and Discussions}

\subsection{Convergent Validity}

The following results of convergent validity tests are presented in Table 1.

Tabel 1

Convergent Validity

\begin{tabular}{llll}
\hline Construct & Indicator & Outer Loading & Desc. \\
\hline \multirow{5}{*}{ Perceived usefullness $(X 1)$} & X11 & 0,671 & Valid \\
& X12 & 0,752 & Valid \\
& X13 & 0,751 & Valid \\
& X14 & 0,728 & Valid \\
& X21 & 0,705 & Valid \\
Perceived ease of use (X2) & X22 & 0,799 & Valid \\
& X23 & 0,728 & Valid \\
& X24 & 0,772 & Valid \\
Attitude toward using (Y1) & Y11 & 0,869 & Valid \\
& Y12 & 0,887 & Valid \\
& Y13 & 0,846 & Valid \\
& Y14 & 0,851 & Valid \\
Behavioral intention of use (Y2) & Y21 & 0,779 & Valid \\
& Y23 & 0,821 & Valid \\
& Y24 & 0,752 & Valid \\
\hline
\end{tabular}

The test results in Table 1 show that the entire outer loading has a value greater than 0.5 , so this measurement can be concluded to have met the requirements of convergent validity.

\subsection{Discriminant Validity}

Validity test is also done by testing method comparing the square root of average variance extracted (AVE) value in each construct with a correlation between other constructs contained in the model. The results of discriminant validity testing are presented in Table 2 .

Tabel 2

Discriminant Validity

\begin{tabular}{llll}
\hline Construct & Indicator & $A V E$ & Desc. \\
\hline Perceived usefullness & $\mathrm{X} 1$ & 0,745 & Reliabel \\
Perceived ease of use & $\mathrm{X} 2$ & 0,593 & Reliabel \\
Attitude toward using & $\mathrm{Y} 1$ & 0,565 & Reliabel \\
Behavioral intention of use & $\mathrm{Y} 2$ & 0,527 & Reliabel \\
\hline
\end{tabular}

The test results in Table 2 explain that the AVE value in the research variable has a value above 0.5 , so that this measurement can be explained to meet the requirements for measuring discriminant validity.

3.3 Composite reliability

Composite reliability testing aims to test the reliability of instruments in a research model. The composite reliability test results are presented in Table 3.

Melaning, A., \& Giantari, I. G. A. K. (2019). Technology acceptance application model on internet banking service in BRI Bank Denpasar Indonesia. International Research Journal of Management, IT and Social Sciences, 6(4), 135 146. https://doi.org/10.21744/irjmis.v6n4.667 
Tabel 3

Composite Reliability

\begin{tabular}{llll}
\hline Construct & Indicator & Composite Reliability & Desc. \\
\hline Perceived usefullness & $\mathrm{X} 1$ & 0,921 & Reliabel \\
Perceived ease of use & $\mathrm{X} 2$ & 0,853 & Reliabel \\
Attitude toward using & $\mathrm{Y} 1$ & 0,838 & Reliabel \\
Behavioral intention of use & $\mathrm{Y} 2$ & 0,817 & Reliabel \\
\hline
\end{tabular}

Based on Table 3, it can be explained that the results of composite reliability testing show good results because all latent variables are reliable because they have a composite reliability value greater than 0.7 . This shows that all indicators are used to measure the constructs of each.

\subsection{Outer Loading}

In a study the value of outer loading is also important to note, the value of the loading factor shows the weight of an indicator against the variable. The largest outer loading value explains that the indicator is said to measure the dominant variable. The results of the outer loading indicator of all variables can be seen in Table 4 .

Tabel 4

Outer Loading Value

\begin{tabular}{lll}
\hline Konstruk/ variabel & Indikator & Outer Loading \\
\hline & $\mathrm{X} 1.1$ & 0,671 \\
Perceived usefullness $(X 1)$ & $\mathrm{X} 1.2$ & 0,752 \\
& $\mathrm{X} 1.3$ & 0,751 \\
& $\mathrm{X} 1.4$ & 0,728 \\
& $\mathrm{X} 1.5$ & 0,705 \\
Perceived ease of use $(X 2)$ & $\mathrm{X} 2.1$ & 0,799 \\
& $\mathrm{X} 2.2$ & 0,728 \\
& $\mathrm{X} 2.3$ & 0,772 \\
Attitude toward using $(Y 1)$ & $\mathrm{X} 2.4$ & 0,869 \\
& $\mathrm{Y} 1.1$ & 0,887 \\
& $\mathrm{Y} 1.2$ & 0,846 \\
& $\mathrm{Y} 1.3$ & 0,851 \\
Behavioral intention of use $(Y 2)$ & $\mathrm{Y} 1.4$ & 0,779 \\
& $\mathrm{Y} 1.1$ & 0,821 \\
& $\mathrm{Y} 1.2$ & 0,752 \\
& $\mathrm{Y} 1.3$ & 0,726 \\
\hline
\end{tabular}

Goodness of Fit - Inner Model (Structural Model)

Goodnes of fit structural models on the inner model are tested using values predictive - relevance (Q2). The R2 value of each endogenous variable in this study can be seen in Table 5.

Table 5

$\mathrm{R}^{2}$

\begin{tabular}{ll}
\hline Variabel Endogen & R-Square \\
\hline Attitude toward using & 0,433 \\
Behavioral intention of use & 0,585 \\
\hline
\end{tabular}

Predictive value - relevance is obtained by the formula: 
$\mathrm{Q}^{2}=1-\left(1-\mathrm{R} 1^{2}\right)\left(1-\mathrm{R} 2^{2}\right)$

$\mathrm{Q}^{2}=1-(1-0.433)(1-0.585)$

$\mathrm{Q}^{2}=1-(0.567)(0.415)$

$\mathrm{Q}^{2}=0,7647$

The above results indicate predictive value - relevance of 0.7647 , this value $>0$ so that it can be interpreted that 76.47 percent of the variation in the variable is explained by the variables used in the model. The remaining 23.53 percent is explained by other factors outside the model. Thus, this model has a relevant predictive value.

\section{Partial Least Square (PLS)}

Testing the hypothesis using Partial Least Square (PLS) will show a number of hypotheses. This test is carried out by using the $\mathrm{t}$ test ( $\mathrm{t}$-test) on each path of influence between variables. In PLS, a statistical test of each hypothesized relationship is carried out using simulation. In this case the bootstrap method is performed on the sample. Bootstrap testing is also intended to minimize the problem of research data abnormalities. The test results with bootstrapping from PLS analysis can be seen in Table 6.

Table 6

Partial Least Square

\begin{tabular}{|c|c|c|c|c|c|}
\hline & $\begin{array}{l}\text { Original } \\
\text { Sample } \\
\text { (O) }\end{array}$ & $\begin{array}{l}\text { Sample } \\
\text { Mean (M) }\end{array}$ & $\begin{array}{l}\text { Standard } \\
\text { Deviation } \\
\text { (STDEV) }\end{array}$ & $\begin{array}{l}\text { T Statistics } \\
(|\mathrm{O} / \mathrm{STDEV}|)\end{array}$ & P Values \\
\hline $\begin{array}{l}\text { Attitude Toward Using -> Behavioral } \\
\text { Intention Of Use }\end{array}$ & 0,471 & 0,462 & 0,080 & 5,902 & 0,000 \\
\hline $\begin{array}{l}\text { Perceived Ease Of Use -> Attitude } \\
\text { Toward Using }\end{array}$ & 0,523 & 0,522 & 0,087 & 5,983 & 0,000 \\
\hline $\begin{array}{l}\text { Perceived Ease Of Use -> Behavioral } \\
\text { Intention Of Use }\end{array}$ & 0,259 & 0,268 & 0,079 & 3,293 & 0,001 \\
\hline $\begin{array}{l}\text { Perceived Usefullness -> Attitude } \\
\text { Toward Using }\end{array}$ & 0,193 & 0,199 & 0,076 & 2,546 & 0,011 \\
\hline $\begin{array}{l}\text { Perceived Usefullness -> Behavioral } \\
\text { Intention Of Use }\end{array}$ & 0,148 & 0,149 & 0,067 & 2,200 & 0,028 \\
\hline
\end{tabular}

The effect of perceived usefulness on attitude toward using

The probability of perceived usefulness towards attitude toward using is 0.011 which is smaller than cut off value $(0.011<0.05)$, so that H0 is rejected. This shows that at the 5 percent significance level, perceived usefulness has a significant effect on attitude toward using.

The results of this study are consistent with the results of previous studies in which Chau \& Lai (2003) and Widyarini (2005), found that the usefulness had a positive and significant effect on attitudes toward using internet banking. Usefulness by Rocker (2009), is defined as a level where a person believes that the use of a particular technology will improve the work performance of that person. The measurement of benefits is based on the frequency of use and diversity of applications that are run.

\section{The effect of perceived ease of use on attitude toward using}

The probability of perceived ease of use on attitude toward using is 0,000 smaller than cut off value $(0,000<0,05)$, so that $\mathrm{H} 0$ is rejected. This shows that at the 5 percent significance level, perceived ease of use has a significant effect on attitude toward using.

The results of this study support the results of previous studies where Rocker (2009); Medyawati et al., (2011), in the results of his research found that perceived ease of use is positively and significantly related to the attitude toward using internet banking. Wen-Chia Tsai (2012), defines ease of use as a level where one believes that computers can be

Melaning, A., \& Giantari, I. G. A. K. (2019). Technology acceptance application model on internet banking service in BRI Bank Denpasar Indonesia. International Research Journal of Management, IT and Social Sciences, 6(4), 135 146. https://doi.org/10.21744/irjmis.v6n4.667 
easily understood. Medyawati et al., (2011), states that the ease of use of internet banking makes customers use it more often. If a convenience has been felt by customers in using internet banking will bring many benefits to customers.

\section{The effect of perceived usefulness on the behavioral intention of use}

The probability of perceived usefulness to the behavioral intention of use is 0.028 which is smaller than the cut off value $(0.028<0.05)$, so that $\mathrm{H} 0$ is rejected. This shows that at the 5 percent significance level, perceived usefulness has a significant effect on the behavioral intention of use.

The results of this study support the results of previous studies in which Rocker (2009), mentions in his research that perceived usefulness is the extent to which individuals believe that using a particular system will be beneficial and improve the performance of their work. Shun Wang et al., (2003), that benefit perception is the definition by which someone believes that using a system can improve their performance. Behavioral intention to use is a behavioral tendency to keep applying technology (Yahyapour, 2008). The level of use of an Internet Banking technology on a person can be predicted from the user's attitude and attention to the technology.

\section{The effect of perceived ease of use on the behavioral intention of us}

The probability of perceived ease of use towards the behavioral intention of use is 0.001 which is smaller than the cut off value $(0.001<0.05)$, so that $\mathrm{H} 0$ is rejected. This shows that at the 5 percent significance level, perceived ease of use has a significant effect on the behavioral intention of use.

The results of this study support the results of previous studies in which Perceived ease of use explained that the extent to which individuals believed that using a particular system would be free from the physical and mental efforts of Chuttur (2009). Perceived ease of use of a technology is defined as a measure where one believes that a technology can be easily understood and used. Behavioral intention to use is a behavioral tendency to keep applying technology. The level of use of an Internet Banking technology on a person can be predicted from the attitude and attention of the user towards the technology.

\section{The effect of attitude toward using the behavioral intention of use}

The probability of the attitude toward using the behavioral intention of use is 0,000 which is smaller than the cut off value $(0,000<0,05)$, so that $\mathrm{H} 0$ is rejected. This shows that at the 5 percent significance level, attitude toward using has a significant effect on the behavioral intention of use.

The results of this study support the results of previous research in which interest (intention) is one of the psychological aspects of humans that can encourage to achieve goals. According to Kusuma (2009), someone who has an interest in an object, tends to give attention or feel greater pleasure to the object. An individual when assessing something that is beneficial to him then at that time he will be interested in using it again and will bring satisfaction. This statement is reinforced by research conducted by Suh \& Han (2002), which examined the effect of trust in the acceptance of internet banking customers where research subjects were in Korea. Based on research conducted by Suh \& Han (2002), the results show that attitude toward using internet banking has a significant effect on interest in using internet banking.

Table 7

Path Coefficients on PLS Methods

\begin{tabular}{|c|c|c|c|c|}
\hline & $\begin{array}{l}\text { Original } \\
\text { Sample }(O)\end{array}$ & $\begin{array}{l}\text { Sample } \\
\text { Mean (M) }\end{array}$ & $\begin{array}{l}\text { Standard } \\
\text { Deviation } \\
(\mathrm{STDEV}) \\
\end{array}$ & $\begin{array}{l}\text { Standard Error } \\
\text { (STERR) }\end{array}$ \\
\hline $\begin{array}{l}\text { Attitude Toward Using -> Behavioral } \\
\text { Intention Of Use }\end{array}$ & 0,471 & 0,462 & 0,080 & 0,080 \\
\hline $\begin{array}{l}\text { Perceived Ease Of Use -> Attitude Toward } \\
\text { Using }\end{array}$ & 0,523 & 0,522 & 0,087 & 0,087 \\
\hline $\begin{array}{l}\text { Perceived Ease Of Use-> Behavioral } \\
\text { Intention Of Use }\end{array}$ & 0,259 & 0,268 & 0,079 & 0,079 \\
\hline
\end{tabular}


Perceived Usefullness -> Attitude Toward

0,193

0,199

0,076

0,076

Using

Perceived Usefullness -> Behavioral

0,148

0,149

0,067

0,067

Intention Of Use

The standard error coefficients a and b are written with $\mathrm{Sa}$ and $\mathrm{Sb}$, the magnitude of the standard indirect error (indirect effects), Sab is calculated by the formula:

$S a b=\sqrt{ } b^{2} S a^{2}+a^{2} S b^{2}+S a^{2} S b^{2}$

To test the significance of the indirect effect then calculate the value of $\mathrm{t}$ from the coefficient ab with the formula:

$$
t=\begin{aligned}
& a b \\
& S a b
\end{aligned}
$$

The value of $t$ value is compared with $t$ table and if $t$ value is greater than the value of $t$ table (>1.96) it can be concluded that there is a significant mediation effect.

The value of the direct effect of the perceived usefulness variable on the behavioral intention of use is 0.148 (shown in table 5.14)

P1 = Perceived usefulness $->$ Attitude toward using $=0.193$

$\mathrm{P} 2=$ Attitude toward using $->$ behavioral intention of use $=0.471$

$\mathrm{Se} 1=0.076$

$\mathrm{Se} 2=0.080$

The size of the indirect efficiency variable perceived usefulness intention of use is the multiplication of the effects of perceived usefulness variables on the attitude variable toward using the attitude toward using the behavioral intention of use so that it is obtained as follows

$\mathrm{P} 12=\mathrm{P} 1 . \mathrm{P} 2$

$\mathrm{P} 12=(0.193) .(0.471)$

$\mathrm{P} 12=0.091$

The standard indirect error perceived usefulness for the behavioral intention of use is the multiplication of the perceived usefulness effect on attitude toward using with attitude toward using the behavioral intention of use so that it is obtained as follows.

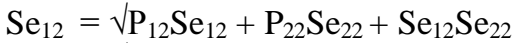

$$
\begin{aligned}
& =\sqrt{ }(0,193)^{2}(0,076)^{2}+(0,471)^{2}(0,080)^{2}+(0,076)^{2}(0,080)^{2} \\
& =, 0000,000215+0,001420+0,000037 \\
& =\sqrt{ } 0.001672 \\
& =0.040889
\end{aligned}
$$

So, the result of t test is:

$$
\begin{gathered}
t=P 12=0,091=2,223 \\
\text { Se } 12 \quad 0,040889
\end{gathered}
$$

The $t$ value is 2,223 where the value is greater than 1.96 which means that the mediation parameter is significant. Thus the attitude model toward using mediates the effect of perceived usefulness on the behavioral intention of use can be accepted.

Attitude toward using mediating the effect of perceived ease of use on the behavioral intention of use

The value of the direct effect of the variable perceived ease of use on the behavioral intention of use is -0.295 (shown in table 7)

$\mathrm{P} 1=$ perceived ease of use $\rightarrow$ attitude toward using $=0.523$

$\mathrm{P} 2=$ attitude toward using $->$ behavioral intention of use $=0.471$

$\mathrm{Se} 1=0.087$

$\mathrm{Se} 2=0.080$

Melaning, A., \& Giantari, I. G. A. K. (2019). Technology acceptance application model on internet banking service in BRI Bank Denpasar Indonesia. International Research Journal of Management, IT and Social Sciences, 6(4), 135146. https://doi.org/10.21744/irjmis.v6n4.667 
The magnitude of the indirect variable coefficient perceived ease of behavior toward the intention of use is multiplication of the effect of the variable perceived ease of use on the attitude variable using attitude toward using the behavioral intention of use so that it is obtained as follows

$\mathrm{P} 12=\mathrm{P} 1 . \mathrm{P} 2$

$\mathrm{P} 12=(0.523) .(0.471)$

$\mathrm{P} 12=0.246$

The indirect standard error perceived ease of use on the behavioral intention of use is the multiplication of the effect of perceived ease of use on attitude toward using the behavioral intention of use so that it is obtained as follows.

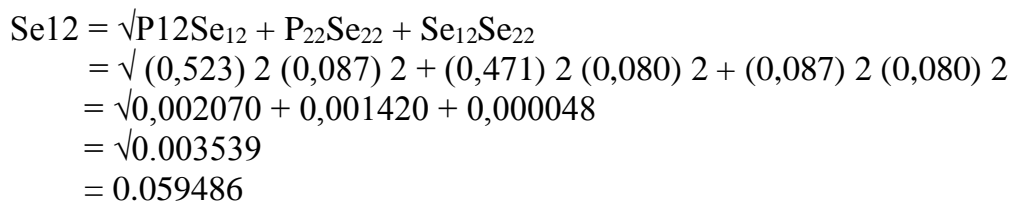

Thus the $\mathrm{t}$ test can be obtained as follows

$t=P 12=0,246=4,141$

Se12 0,059486

The t value of 4.141 is greater than 1.96 , which means that the mediation parameter is significant. Thus the attitude model using mediating the effect of perceived ease of use on the behavioral intention of use is acceptable.

\section{Conclusion}

To increase perceived usefulness, internet banking applications must enhance the effectiveness of customer banking transactions, so that customers will increasingly feel the benefits of using the application. To improve the perceived ease of use, internet banking applications must be flexible, can be used anywhere and anytime, so that customers will increasingly feel the ease felt in using the application. To improve the attitude toward using, internet banking applications must maintain customer confidentiality, so that customers will be more secure in using the application. To improve the behavioral intention of use, internet banking applications must be able to help in every transaction, so customers will want to use the internet banking application.

\section{Conflict of interest statement and funding sources}

The authors declared that they have no competing interest.

\section{Statement of authorship}

The authors have a responsibility for the conception and design of the study. The authors have approved the final article.

\section{Acknowledgments}

The authors would like to thank the Editor of IRJMIS for their valuable time, support, and advice in completing the current study. 


\section{References}

Ahmad, K., \& Pan, W. (2008). Hybrid nanocomposites: a new route towards tougher alumina ceramics. Composites Science and Technology, 68(6), 1321-1327. https://doi.org/10.1016/j.compscitech.2007.12.011

Alamsyah, D. P., \& Anugrah, R. (2015). Membangun Kepercayaan Nasabah Pada Internet Banking. Jurnal Ecodemica: Jurnal Ekonomi, Manajemen, dan Bisnis, 3(2), 464-473.

Aldás-Manzano, J., Lassala-Navarré, C., Ruiz-Mafé, C., \& Sanz-Blas, S. (2009). The role of consumer innovativeness and perceived risk in online banking usage. International Journal of Bank Marketing, 27(1), 53-75. https://doi.org/10.1108/02652320910928245

Aldas-Manzano, J., Ruiz-Mafe, C., Sanz-Blas, S., \& Lassala-Navarré, C. (2011). Internet banking loyalty: evaluating the role of trust, satisfaction, perceived risk and frequency of use. The Service Industries Journal, 31(7), 11651190. https://doi.org/10.1080/02642060903433997

Chanana, M., \& Gupta, K. (2016). Quality of work life and its impact on job performance: a study of S.B.I \& HDFC banking professionals. International Research Journal of Management, IT and Social Sciences, 3(5), 16-24.

Chau, P. Y., \& Lai, V. S. (2003). An empirical investigation of the determinants of user acceptance of internet banking. Journal of organizational computing and electronic commerce, 13(2), 123-145. https://doi.org/10.1207/S15327744JOCE1302_3

Chuttur, M. Y. (2009). Overview of the technology acceptance model: Origins, developments and future directions. Working Papers on Information Systems, 9(37), 9-37.

Cohen-Kerem, R., \& Koren, G. (2003). Antioxidants and fetal protection against ethanol teratogenicity: I. Review of the experimental data and implications to humans. Neurotoxicology and teratology, 25(1), 1-9. https://doi.org/10.1016/S0892-0362(02)00324-0

Davis, F. D. (1985). A technology acceptance model for empirically testing new end-user information systems: Theory and results (Doctoral dissertation, Massachusetts Institute of Technology).

Davis, R. J. (2000). Signal transduction by the JNK group of MAP kinases. In Inflammatory Processes: (pp. 13-21). Birkhäuser, Basel. https://doi.org/10.1007/978-3-0348-8468-6_2

Dewi, I. G. A. A. O., \& Dewi, I. G. A. A. P. (2017). Corporate social responsibility, green banking, and going concern on banking company in Indonesia stock exchange. International Journal of Social Sciences and Humanities, 1(3), 118-134. https://doi.org/10.29332/ijssh.v1n3.65

Hoppe, R., Newman, P., \& Mugera, P. (2001). Factors affecting the adoption of internet banking in South Africa: a comparative study. Department of Information Systems, University of Cape Town, South Africa, 17.

Indonesia, B. (2004). Surat Edaran Bank Indonesia No.

Kustina, K. T., Dewi, I. G. A. A. O., Prena, G. D., \& Utari, I. G. A. D. (2018). MSMEs credit distribution and nonperforming loan towards banking companies profit in Indonesia. International Journal of Social Sciences and Humanities, 2(1), 10-23. https://doi.org/10.29332/ijssh.v2n1.72

Kusuma, H., \& Susilowati, D. (2007). Determinan Pengadopsian Layanan Internet Banking: Perspektif Konsumen Perbankan Daerah Istimewa Yogyakarta. Indonesian Journal of Accounting and Auditing, 11(2).

Kusuma, V. A., Freeman, B. D., Borns, M. A., \& Kalika, D. S. (2009). Influence of chemical structure of short chain pendant groups on gas transport properties of cross-linked poly (ethylene oxide) copolymers. Journal of Membrane Science, 327(1-2), 195-207. https://doi.org/10.1016/j.memsci.2008.11.022

Lech, P. (2012). Information gathering during enterprise system selection: insight from practice. Industrial Management \& Data Systems, 112(6), 964-981. https://doi.org/10.1108/02635571211238545

Lee, D. S., \& Lemieux, T. (2010). Regression discontinuity designs in economics. Journal of economic literature, 48(2), 281-355.

Medyawati, H., Christiyanti, M., \& Yunanto, M. (2011). E-banking adoption analysis using technology acceptance model (TAM): Empirical study of bank customers in Bekasi city. International Co/! ference 011lllnovatioll, Mallagemellt and Service, 14.

Rigopoulos, G., \& Askounis, D. (1970). A TAM Framework to Evaluate Users $\tilde{A} \varnothing \hat{A}$ Â Perception towards Online Electronic Payments. The Journal of Internet Banking and Commerce, 12(3), 1-6.

Röcker, C. (2009, July). Perceived usefulness and perceived ease-of-use of ambient intelligence applications in office environments. In International Conference on Human Centered Design (pp. 1052-1061). Springer, Berlin, Heidelberg. https://doi.org/10.1007/978-3-642-02806-9_120

Sanjaya, I. P. S. (2008). Auditor Eksternal, Komite Audit, dan Manajemen Laba Sanjaya. The Indonesian Journal of Accounting Research, 11(1).

Melaning, A., \& Giantari, I. G. A. K. (2019). Technology acceptance application model on internet banking service in BRI Bank Denpasar Indonesia. International Research Journal of Management, IT and Social Sciences, 6(4), 135146. https://doi.org/10.21744/irjmis.v6n4.667 
Suh, B., \& Han, I. (2003). The impact of customer trust and perception of security control on the acceptance of electronic commerce. International Journal of electronic commerce, 7(3), 135-161. https://doi.org/10.1080/10864415.2003.11044270

Suryasa, I. W., Prayoga, I. G. P. A., \& Werdistira, I. W. A. (2018). Attitudes toward the use of internet for students. International Journal of Physical Sciences and Engineering, 2(2), 32-38. https://doi.org/10.29332/ijpse.v2n2.141

Tampubolon, N. (2004). Surat edaran: Penerapan manajemen risiko pada aktivitas pelayanan jasa bank melalui internet (internet banking). August, 24, 2005.

Tsai, W. C. (2012). A study of consumer behavioral intention to use e-books: the technology acceptance model perspective. Innovative Marketing, 8(4), 55-66.

Udayana, I. G. B. (2017). Marketing strategies arabica coffee with information technology in Kintamani District Bangli. International Research Journal of Engineering, IT \& Scientific Research, 3(3), 93-102.

Wang, Y. S., Wang, Y. M., Lin, H. H., \& Tang, T. I. (2003). Determinants of user acceptance of Internet banking: an empirical study. International journal of service industry management, 14(5), 501-519. https://doi.org/10.1108/09564230310500192

Wibowo, A. (2008). Kajian tentang perilaku pengguna sistem informasi dengan pendekatan technology acceptance model (TAM). Konferebsi Nasional Sistem Informasi.

Widyarini, L. A. (2005). Analisis Niat Perilaku Menggunakan Internet Banking Di kalangan Pengguna Internet Di Surabaya. Widya Journal of Management and Accounting, 5(1).

Yahyapour, N. (2008). Determining factors affecting intention to adopt banking recommender system: case of Iran.

Yoga, P. (2012). 85\% Transaksi Lewat E-Channel, Bank Mandiri Klaim Makin Efisien. 